\title{
Sampling Methods and Risk Stratification Regarding Environmental Contamination by SARS-CoV-2
}

\author{
Métodos de Colheita de Amostras e Estratificação de Risco \\ Relativo à Contaminação Ambiental pelo SARS-CoV-2
}

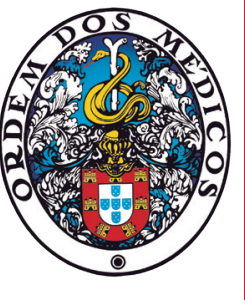

\author{
Marta MENDES ${ }^{* 1}$, Ana ANDRADE OLIVEIRA $\rrbracket^{* 1}$, Olga PIRES ${ }^{1}$, Fernando BRANCA², Maria BEIRÃO², \\ André SANTA-CRUZ $Z^{1,3,4}$, Alexandre CARVALHO ${ }^{1,3,4}$, Joana ALVES ${ }^{5}$ \\ Acta Med Port 2021 Dec;34(12):851-856 - https://doi.org/10.20344/amp.16215
}

\section{ABSTRACT}

Introduction: Transmission of COVID-19 through close contact and droplets is well established, but the influence of aerosol and surface contamination remains to be determined. Literature is scarce and inconsistent about the viable virus particles free-distancefrom infected patients, as well as about different swabbing methods for surface contamination evaluation. The aim of this study was to evaluate the most sensitive method for the assessment of surface contamination, classify the likelihood of environmental contamination in risk zones and compare the environmental contamination between oxygenation and ventilatory support.

Material and Methods: Swabs from potentially contaminated surfaces in a COVID-19 ward, with patients treated with different types of oxygen and ventilatory support, were collected. Three types of swabs were compared in order to evaluate the most sensitive collection method. For risk zone categorization, areas were divided according to the distance from the patient.

Results: Of the 63 swabs collected, 17 (27\%) tested positive for the presence of SARS-CoV-2. The highest positivity rate was observed with the sterile premoistened swab with saline $(n=8 ; 38 \%)$, but without statistically significant differences. The highest number of positive samples were collected from the high-risk zones, specifically those located one meter from the patient $(n=13 ; 48 \%)$, with statistically significant differences. Only the rooms of patients supported with non-invasive ventilation or high-flow nasal cannula had evidence of bedroom contamination, with $45 \%$ and $27 \%$ of swab positivity, with statistically significant differences.

Discussion: Our findings favour the premoistened swab without transport medium for surface contamination assessment, even though without statistical differences. A statistically significant trend supporting the division in risk zones, according to the distance from the patient, was also identified. The higher positivity rate from the non-invasive ventilation and high-flow nasal cannula bedrooms suggests a significant association between ventilatory strategies and surface contamination, probably due to higher particle dispersion.

Conclusion: Our findings support the use of the sterile premoistened swab without preservation medium, the classification of risk areas considering the distance from the patient, and the variability of RNA dispersion between oxygenation and ventilatory support.

Keywords: Aerosols; COVID-19; Equipment Contamination; SARS-CoV-2

\section{RESUMO}

Introdução: A transmissão da COVID-19 através do contacto e gotículas está bem estabelecida, mas a importância da sua transmissão através do aerossol e da contaminação das superfícies permanece por determinar. A literatura é escassa e inconsistente em relação à distância mínima livre de partículas víricas, desde um paciente, e também acerca dos mais adequados métodos de colheita de zaragatoas para avaliação da contaminação das superfícies. Os objectivos deste estudo foram avaliar qual o método mais sensível para avaliação da contaminação de superfícies, classificar a contaminação ambiental de acordo com zonas de risco e comparar a contaminação ambiental sob diferentes dispositivos para oxigenoterapia e suporte ventilatório.

Material e Métodos: Realizamos colheitas de zaragatoas em superfícies potencialmente contaminadas numa ala COVID-19, onde se encontravam doentes sob diferentes dispositivos para oxigenoterapia e suporte ventilatório. Para avaliar o método de recolha mais sensível para verificação da contaminação das superfícies, comparámos três tipos de zaragatoas. Para a classificação das zonas de risco, dividimos as áreas de acordo com a distância ao doente.

Resultados: Das 63 zaragatoas, 17 (27\%) testaram positivo para SARS-CoV-2 (27\%). A maior positividade foi observada na zaragatoa estéril pré-humedecida com soro fisiológico $(n=8 ; 38 \%)$, mas sem significância estatística. O maior número de amostras positivas obteve-se nas zonas de alto risco, especialmente aquelas a um metro do paciente $(n=13 ; 48 \%)$, com diferenças significativas. Apenas os quartos dos doentes sob ventilação não invasiva e cânula nasal de alto fluxo tiveram evidência de contaminação com $45 \%$ e $27 \%$ de positividade das zaragatoas, e significância estatística.

Discussão: Os nossos resultados favorecem a zaragatoa estéril pré-humedecida sem meio de preservação para avaliação da contaminação das superfícies, embora sem significância estatística. Os resultados suportam também com significância estatística a divisão em zonas de risco de acordo com a distância ao doente. A maior positividade obtida nos quartos dos pacientes que se encontravam a utilizar ventilação não invasiva e cânula nasal de alto fluxo sugere uma associação, com significância, entre as estratégias ventilatória e a contaminação ambiental, provavelmente relacionada com uma maior dispersão das partículas.

Conclusão: Os nossos resultados apoiam o uso da zaragatoa estéril pré-humedecida sem meio de preservação, a classificação das

* Joint first authors. Both authors contributed equally for the article.

1. Department of Internal Medicine. Hospital of Braga. Braga. Portugal.

2. Department of Molecular Biology. Hospital of Braga. Braga. Portugal.

3. Life and Health Sciences Research Institute. School of Medicine. University of Minho. Braga. Portugal.

4. Life and Health Sciences Research Institute/ 3B's Research Group - Biomaterials, Biodegradables and Biomimetics - Portuguese Government Associate Laboratory. Braga/ Guimarães. Portugal.

5. Department of Infectious Diseases. Hospital of Braga. Braga. Portugal.

$\triangle$ Autor correspondente: Ana Andrade Oliveira. ana.i.oliveira@hb.min-saude.pt

Recebido: 16 de março de 2021 - Aceite: 26 de Abril de 2021 - First published: 20 de maio de 2021 - Online issue published: 02 de dezembro de 2021 Copyright @ Ordem dos Médicos 2021 
áreas de risco considerando a distância ao doente, e a variabilidade da dispersão do RNA entre diferentes dispositivos para oxigenoterapia e ventilação.

Palavras-chave: Aerossóis; Contaminação de Equipamentos; COVID-19; SARS-CoV-2

\section{INTRODUCTION}

COVID-19 is the most significant worldwide public health emergency in over a century. It is caused by the severe acute respiratory syndrome coronavirus 2 (SARS-CoV-2), a Betacoronavirus of the Coronaviridae family. It is an enveloped virus and has a spherical particle of approximately $120 \mathrm{~nm}$ in diameter containing a positivesense single-stranded RNA genome. ${ }^{1}$

Human coronaviruses can remain infectious in inanimate surfaces at room temperature for up to nine days, and this can potentially contribute to the nosocomial spread of the disease. ${ }^{2}$ There is consensus about the role of respiratory droplets larger than 5 to $10 \mu \mathrm{m}$, and close contacts to the transmission of the infection, but the influence of aerosols smaller than $5 \mu \mathrm{m}$ and surface contamination remains difficult to assess. ${ }^{3-6}$ In fact, the minimum amount of virions needed to infect a new host is still unknown., ${ }^{3,7-15}$ Considering these uncertainties, prevention of transmission has been based on the use of personal protective equipment (PPE), room ventilation, and surface disinfection. . $^{3,9,10}$

Understanding the extent of aerosol dissemination and environmental contamination of SARS-CoV-2 in COVID-19 wards is paramount to the conception of safety practices. ${ }^{5-7,11}$ Therefore, studies that address the extent of environmental contamination are critical for the design of successful preventive measures that can contribute to a decrease in nosocomial dissemination. The few studies published to date can hardly be comparable due to the variability amongst collection methods and lack of stratification in risk zones. . $10,12,16^{2}$

The aim of our study was to evaluate the most sensitive method for the assessment of surface contamination, classify the likelihood of environmental contamination in risk zones and compare the environmental contamination between oxygenation and ventilatory support.

\section{MATERIAL AND METHODS Study location}

From April to June 2020, in a tertiary Portuguese hospital (with an inpatient capacity of 104 COVID-19 beds), swab samples from potentially contaminated areas and objects in selected rooms of a COVID-19 ward were collected. Selected rooms did not have negative pressure, and air was renewed at a rate of three times per hour. Medical and electronic devices were disinfected with wipes $\left(\mathrm{Clinell}^{\circledR}\right.$, Gama Healthcare, UK). The remaining surfaces of the room were sanitized with detergent (Dismofix ${ }^{\circledR}$ and Mikrobac ${ }^{\circledR}, \mathrm{BODE}$, Germany). The floor was sanitized (Flower Easy ${ }^{\circledR}$ detergent, Sutter, Italy).

\section{Selection of collecting methods}

In order to evaluate the most sensitive collection method for the determination of surface contamination, three different types of swabs were used: dry sterile swab without preservation medium, dry sterile swab premoistened with saline, and dry sterile swab dipped in universal transport medium (from Jiangsu Kangjian Medical Apparatus Co.). A total of 63 samples were collected amongst 21 different places, distributed evenly between different types of sampling methods, and performed in the same place and time one centimetre apart (Table 1).

\section{Selection of patient rooms}

In order to compare collection methods, we selected the room of patient One. This patient was on his $9^{\text {th }}$ day of symptoms under non-invasive ventilation (NIV) and was selected based on the assumption that the aerosol dispersion would be higher with this kind of ventilation method. ${ }^{6}$

After the selection of the most adequate collection method, we evaluated the environmental contamination of the rooms of random patients with different oxygen and ventilatory supports and compared it to the room of patient One. Patient Two was admitted due to a surgical condition, was asymptomatic and without supplemental oxygen; patient Three was on his $8^{\text {th }}$ day of symptoms and with oxygen delivered through a Venturi mask with a fraction of inspired oxygen of $31 \%$; patient Four was on his $22^{\text {nd }}$ day of symptoms and under high flow nasal cannula (HFNC).

\section{Definition of collecting areas}

The sampling areas were classified as: high-risk, within one meter from the patient; moderate-risk, within one to two meters from the patient; low-risk, more than two meters away from the patient, as represented in Fig. 1.

In order to evaluate the collection methods, samples were collected from different areas and objects inside patient One's room (Table 1) -bed, NIV outlet, NIV mask, pillow, PPE, room air conduit, floor $(1,1.5$, and two meters from the bed), windowsill, door handles and the zone for the removal of staff PPE, and outside the room - phones and computers, nursing charts, air conduit from the hall, floor of the demarcated dirty zone outside the room and floor of the clean zone outside the room.

Samples were collected from areas and objects inside and outside other three selected rooms in order to compare the dispersion between oxygen and ventilatory support (Table 2) - bed, mask/cannula, air conduit from the patient's room, floor (1, 1.5, and 2 meters from the patient), windowsill, computer inside the room, door handles, the zone for the removal of staff PPE, floor of the dirty zone outside the room and floor of the clean zone outside the room.

\section{Sample collection, conservation, and processing}

After the collection of each sample, the container of the swabs was soaked in $70 \%$ alcohol, allowed to dry, and then sealed with parafilm. Each tube was anonymously identified and delivered to the laboratory. The samples were stored 


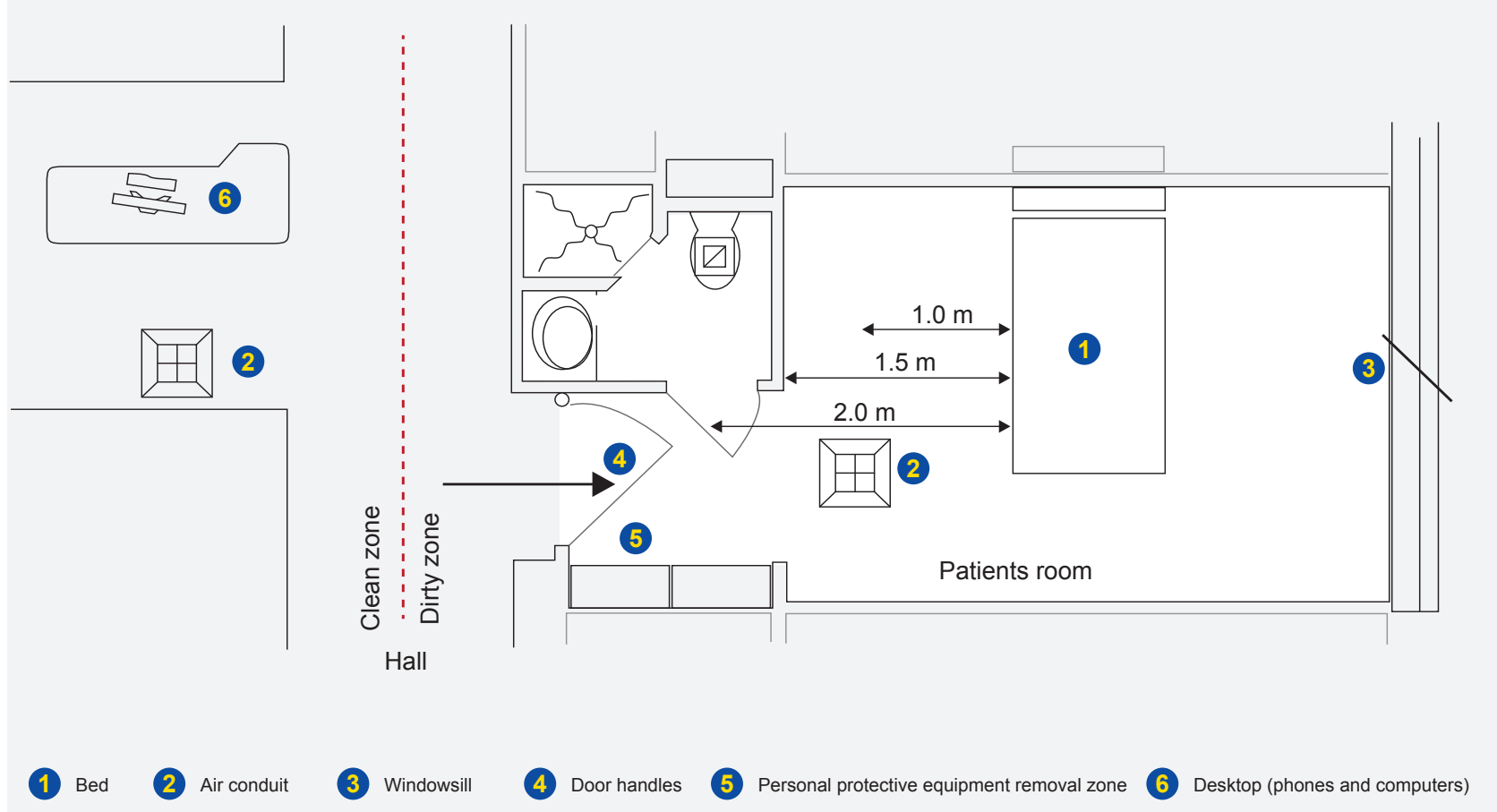

Figure 1 - Representation of the room with identification of the collecting areas and distances

and refrigerated between two and eight degrees Celsius for a maximum of 24 hours before processing.

Swabs were processed using specific real-time reverse transcriptase-polymerase chain reaction (RT-PCR) targeting RNA-dependent RNA polymerase and E-genes were used to detect the presence of SARS-CoV-2.

\section{Statistical analysis}

Statistical analyses were performed using SPSS 22.0 with a confidence interval of $95 \%$. In order to compare groups, chi-square test was applied to compare categorical variables after the verification of its assumptions. The Cramer's $V$ test was applied to test the data when a significant result was obtained.

\section{Ethics}

The present study was conducted following ethical and legal principles. Due to its non-interventional nature, without any collection of patient data, no need for approval by the Ethics Committee was warranted.

\section{RESULTS}

Of the 63 swabs obtained, 17 (27\%) tested positive for SARS-CoV-2 (Table 1). When comparing different swabs, the sterile premoistened swab without preservation medium had a higher positivity rate $(n=8,38 \%)$, allowing the identification of SARS-CoV-2 in four more places compared to the dry swab dipped in universal transport medium - standard method of collection ( $n=4,19 \%)$. When the chi-square test was applied no statistically significant differences were observed $(p=0.351)$. The positivity rate of the dry sterile swab without preservation medium was lower compared to the sterile premoistened swab with saline $(n=5$ vs $n=8)$ and higher compared to the standard method of collection ( $n=5$ vs $\mathrm{n}=4$ ).

The sampling areas were classified according to the proximity from patient one at high, moderate, and low-risk zones. The highest number of positive samples were collected in high-risk zones (13 out of $27,48 \%$ ), followed by the moderate-risk areas (3 out of 15, 20\%). In order to standardize the statistical analysis, the results from the swabs performed after eight hours of NIV were compared. A statistically significant difference between the results obtained and the expected ones (likelihood ratio 14,658; df 2; $p=$ 0.001 ) was found, with the positivity rate from the low-risk zones $(n=1)$ significantly lower than expected, and the positivity rate from the high-risk zones $(n=9)$ significantly higher $(p=0.001)$. The Cramer $\vee$ test confirmed a moderately strong association between the different areas and their positivity (correlation coefficient $=0.531, p=0.001$ ).

No statistically significant difference was observed regarding the positivity rate of the swabs performed after one and eight hours of NIV ( $p=0.168)$.

After the selection of the collection method, we evaluated the environmental contamination of the rooms from patients with different types of oxygenation and ventilatory support (Table 2). The positivity rate was higher in patient One's room ( $n=5,45 \%$ ), followed by patient Four's room $(n=3,27 \%)$. Samples from the rooms of patients Two and Three were all negative. A higher particle dispersion with the NIV is suggested in our study, as the samples of patient One's room were positive in the bed and floor 1.5 and two meters from the patient. In patient Four's room (HFNC) the dispersion of particles was lower, as only swabs from the floor at 1 and $1.5 \mathrm{~m}$ from the patient were positive. In terms of positivity rate, we found statistically significant differences 
Table 1 - Results of surface contamination with SARS-CoV-2 from three different swab types and with a distinction between risk zones.

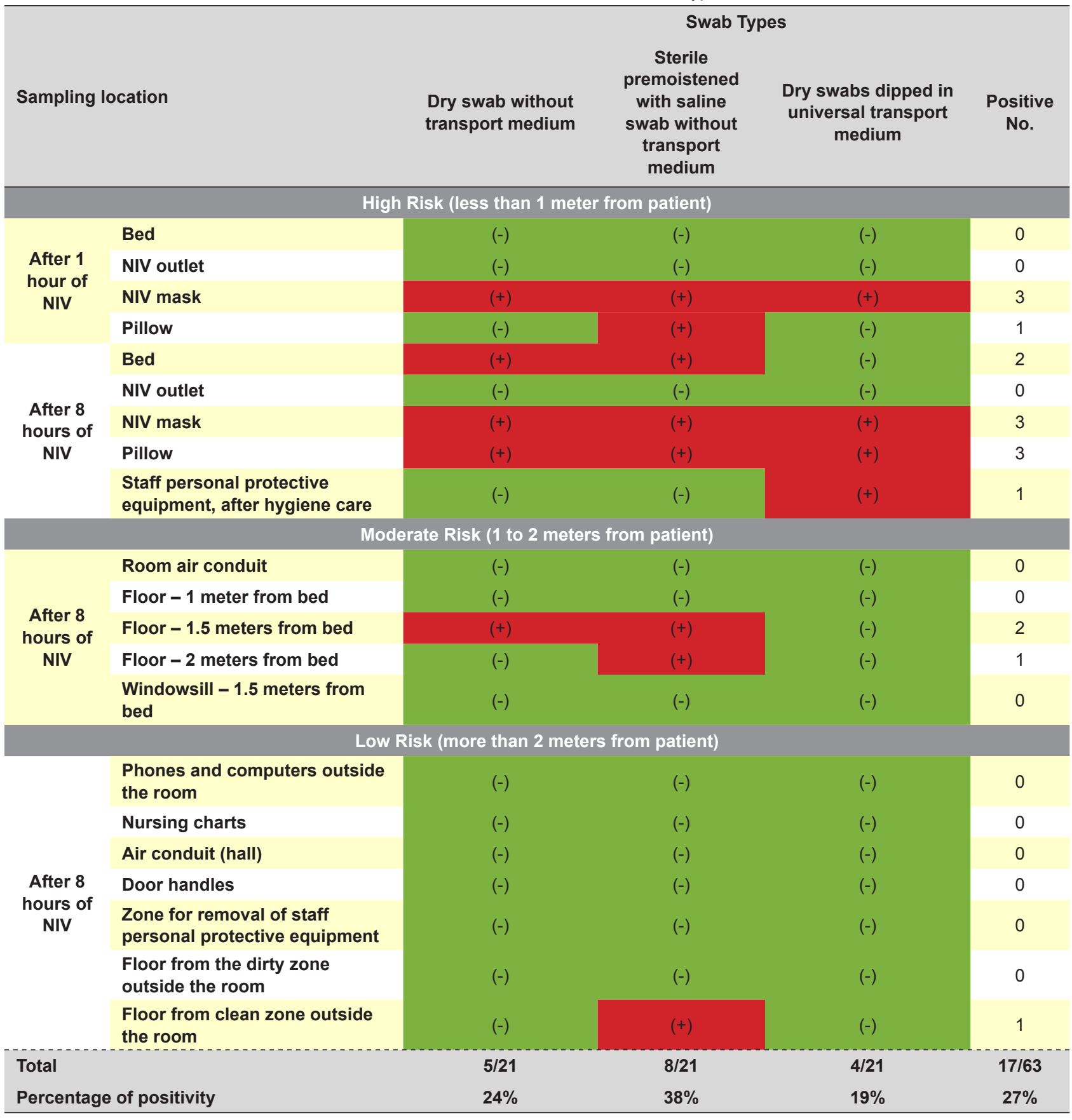

(+): positive for SARS-CoV-2; (-): negative for SARS-CoV-2; NIV: non-invasive ventilation; PPE: personal protective equipment

between the results obtained (likelihood ratio 13.07; df 2; $p=0.04)$, with the Cramer $\mathrm{V}$ test confirming a moderately strong association between the oxygenation and ventilatory support and swab positivity (correlation coefficient $=0.489$, $p=0.014$ ).

Regarding the areas and objects, the positivity rate of the NIV mask, pillow, and the patient's bed in the highrisk areas, and the floor in moderate-risk areas should be highlighted (Tables 1 and 2). The search for SARS-CoV-2 on personal protective equipment, regarded as a high-risk zone, was positive only in the dry swab preserved in the SARS-CoV-2 medium.

\section{DISCUSSION}

Our findings seem to favour the premoistened swab without transport medium evaluating surface contamination due to its higher positivity rate, although without statistically significant differences. These results can be justified by the ability of the premoistened swab to maximize the quantity of RNA removed from the sampling areas compared to the dry swabs. Additionally, the presence of the universal transport medium in the standard collection method can contribute to a dilution of the material collected from areas that already have low RNA content, thus contributing to a lower positivity rate. 
Table 2 - Room surface contamination with SARS-CoV-2 of four different patients, collected with sterile premoistened with a saline swab, and with a distinction between risk zones

\begin{tabular}{|c|c|c|c|c|}
\hline Patients & Patient 1 & Patient 2 & Patient 3 & Patient 4 \\
\hline Type of ventilation & $\begin{array}{l}\text { Non-invasive } \\
\text { ventilation }\end{array}$ & Without oxygen & Ventimask ${ }^{\circledR}$ & $\begin{array}{l}\text { High-flow nasal } \\
\text { cannula }\end{array}$ \\
\hline Symptoms (days) & 9 & Asymptomatic & 8 & 22 \\
\hline Sampling places & \multicolumn{4}{|c|}{ Results } \\
\hline \multicolumn{5}{|c|}{ High Risk (less than 1 meter from patient) } \\
\hline Bed after 8 hours & $(+)$ & $(-)$ & $(-)$ & $(-)$ \\
\hline Mask/cannula & $(+)$ & NA & $(-)$ & $(+)$ \\
\hline \multicolumn{5}{|c|}{ Moderate Risk ( 1 to 2 meters from patient) } \\
\hline $\begin{array}{l}\text { Air conduit (patient } \\
\text { room, without negative } \\
\text { pressure) }\end{array}$ & $(-)$ & $(-)$ & $(-)$ & $(-)$ \\
\hline Floor - 1 meter from bed & $(-)$ & $(-)$ & $(-)$ & $(+)$ \\
\hline $\begin{array}{l}\text { Floor - } 1.5 \text { meters from } \\
\text { bed }\end{array}$ & $(+)$ & $(-)$ & $(-)$ & $(+)$ \\
\hline Floor -2 meters from bed & $(+)$ & $(-)$ & $(-)$ & $(-)$ \\
\hline $\begin{array}{l}\text { Windowsill }-1.5 \text { to } 2 \\
\text { meters from bed }\end{array}$ & $(-)$ & $(-)$ & $(-)$ & $(-)$ \\
\hline $\begin{array}{l}\text { Computer inside the room } \\
-1.7 \text { meters from bed }\end{array}$ & NA & NA & NA & $(-)$ \\
\hline \multicolumn{5}{|c|}{ Low Risk (more than 2 meters from patient) } \\
\hline Door handles & $(-)$ & $(-)$ & $(-)$ & $(-)$ \\
\hline $\begin{array}{l}\text { Zone for removal of } \\
\text { staff personal protective } \\
\text { equipment }\end{array}$ & $(-)$ & $(-)$ & $(-)$ & $(-)$ \\
\hline $\begin{array}{l}\text { Floor from the dirty zone } \\
\text { outside the room }\end{array}$ & $(-)$ & $(-)$ & $(-)$ & $(-)$ \\
\hline $\begin{array}{l}\text { Floor from clean zone } \\
\text { outside the room }\end{array}$ & $(+)$ & $(-)$ & $(-)$ & $(-)$ \\
\hline Total & $5 / 11$ & $0 / 10$ & $0 / 11$ & $3 / 11$ \\
\hline Percentage of positivity & $45 \%$ & $0 \%$ & $0 \%$ & $27 \%$ \\
\hline
\end{tabular}

(+): positive for SARS-CoV-2; (-): negative for SARS-CoV-2; NA: non-applicable; NIV: non-invasive ventilation; HFNC: high flow nasal canula

The results also support, with statistical significance, the division in risk zones according to the distance from the patient. This is a meaningful finding since it can have a huge impact not only on the design of the new studies about environmental contamination but also on the organization and practices of COVID-19 wards.

A statistically significant association was also found between oxygenation and ventilatory strategies and environmental contamination. A higher positivity rate was found with NIV and HFNC, in accordance with previous studies that demonstrated a lower dispersion with HFNC (maximum of $17.2 \mathrm{~cm}$ at $60 \mathrm{~L} / \mathrm{min}$ ) than with NIV (maximum of 92 $\mathrm{cm}){ }^{6-17}$ The negative results in the rooms of the asymptomatic patient and the patient using a Venturi mask, reinforces the lower dispersion of particles in these patients. ${ }^{6}$

Although, NIV and HFNC have been categorized as aerosol-generating procedures, their potential for increased aerosol generation, dispersion, and infectiousness is still controversial. ${ }^{5-13}$ Despite the large number of studies published about aerosol transmission, the amount of RNA necessary to cause infection remains unclear, so one cannot state that the presence of viral RNA signifies an infectious potential..$^{5-8}$ In our study, the negative results from the windowsill and air conduit do not substantiate the possibility of extensive aerosolization.

The positive results in the floor samples probably resulted from particle dispersion caused by footwear and not dispersion through aerosols; these findings are in accordance with previous descriptions of high number of positive floor samples probably resulting from gravity, airflow, and dispersion by walking. ${ }^{11}$

The absence of statistical differences between the positivity rates after one hour and eight hours of NIV exposure may be explained by the small sample size.

The isolated positivity of the standard collection method in staff PPE was probably due to a contact with a contaminated area. Given the small number of samples taken, we cannot conclude through these results what the degree of PPE contamination is. PPE reduces the transmission of the disease to healthcare professionals if properly used. . $^{6,15}$

Our findings demonstrate low environmental contamination and are in accordance with other studies showing a 
less extensive surface contamination than previously supposed. ${ }^{7,9-12}$ The low positivity rate of overall samples can be explained by the implementation of adequate hygiene procedures and air renewals. Studies reported a reduction in the concentration of RNA in aerosols to an undetected level after the implementation of sanitizing procedures. ${ }^{3}$ Environmental cleaning and disinfection reduce the contamination of surfaces and inanimate objects, contributing to the reduction of the inoculum and lowering the risk of infection.

Our study presents limitations that can hinder conclusions, such as the low number of samples, the selection of patients on different days of symptoms, and lack of RNA quantification. However, we think this does not change the relevance of our work and its results, since it can contribute to the design of future studies.

\section{CONCLUSION}

The findings of our study support the application of the sterile premoistened swab without preservation medium, given its higher positivity rate, and the division in risk areas according to the distance from the patient. Lastly, it also demonstrates a greater particle dispersion with NIV and HFNC. These results may redirect future investigations regarding environmental contamination and aid in the development of more efficient practices and organization of wards dedicated to patients with COVID-19.

\section{AUTHORS CONTRIBUTION}

MFM, AAO: Conception and design of the article; acquisition of the data; collection of the surface's samples; interpretation of the data; drafting the article and revising it critically; final approval.

OP: Collection of the surface's samples; revision and final approval of the article.

FB, MB: Processing the surface's samples; revision and final approval of the article.

ASC, AC: Critical review and final approval of the article.

$\mathrm{JA}$ : Conception and design of the article; acquisition of the data; collection of the surface's samples; critical review and final approval.

\section{PROTECTION OF HUMANS AND ANIMALS}

The authors declare that the procedures were followed according to the regulations established by the Clinical Research and Ethics Committee and to the Helsinki Declaration of the World Medical Association updated in 2013.

\section{DATA CONFIDENTIALITY}

The authors declare having followed the protocols in use at their working center regarding patients' data publication.

\section{COMPETING INTERESTS}

The authors declare that they have no conflict of interest with regard to this article.

\section{FUNDING SOURCES}

This research received no specific grant from any funding agency in the public, commercial, or not-for-profit sectors

\section{REFERENCES}

1. Liu YC, Kuo RL, Shih SR. COVID-19: the first documented coronavirus pandemic in history. Biomed J. 2020;43:328-33.

2. Kampf G, Todt D, Pfaender S, Steinmann E. Persistence of coronaviruses on inanimate surfaces and their inactivation with biocidal agents. J Hosp Infect. 2020;104:246-51. Erratum in: J Hosp Infect. 2020 Jun 17: PMID: 32035997; PMCID: PMC7132493.

3. Liu Y, Ning Z, Chen Y, Guo M, Liu Y, Gali NK, et al. Aerodynamic analysis of SARS-CoV-2 in two Wuhan hospitals. Nature. 2020;582:557-60.

4. Prather KA, Marr LC, Schooley RT, McDiarmid MA, Wilson ME, Milton DK. Airborne transmission of SARS-CoV-2. Science. 2020;370:303-4.

5. Klompas M, Baker M, Rhee C. Airborne transmission of SARSCoV-2: theoretical considerations and available evidence. JAMA. 2020;324:441-2.

6. Ferioli M, Cisternino C, Leo V, Pisani L, Palange P, Nava S. Protecting healthcare workers from SARS-CoV-2 infection: practical indications. Eur Respir Rev. 2020;29:200068.

7. Wang J, Feng $\mathrm{H}$, Zhang $\mathrm{S}$, Ni Z, Ni L, Chen $\mathrm{Y}$, et al. SARS-CoV-2 RNA detection of hospital isolation wards hygiene monitoring during the Coronavirus disease 2019 outbreak in a Chinese hospital. Int J Infect Dis. 2020;94:103-6.

8. Little P, Read R, Amlôt R, Chadborn T, Rice C, Bostock J, et al. Reducing risks from coronavirus transmission in the home-the role of viral load. BMJ. 2020;369:m1728.

9. Colaneri M, Seminari E, Piralla A, Zuccaro V, Filippo AD, Baldanti F, et al. Lack of SARS-CoV-2 RNA environmental contamination in a tertiary referral hospital for infectious diseases in Northern Italy. J Hosp Infect.

2020;105:474-6.

10. Colaneri M, Seminari E, Novati S, Asperges E, Biscarini S, Piralla A, et al. Severe acute respiratory syndrome coronavirus 2 RNA contamination of inanimate surfaces and virus viability in a health care emergency unit. Clin Microbiol Infect. 2020;26:1094.e1-5.

11. Guo ZD, Wang ZY, Zhang SF, Li X, Li L, Li C, et al. Aerosol and surface distribution of severe acute respiratory syndrome Coronavirus 2 in hospital wards, Wuhan, China, 2020. Emerg Infect Dis. 2020;26:158391.

12. Ong S, Tan $\mathrm{Y}$, Chia $\mathrm{P}$, Lee $\mathrm{T}, \mathrm{Ng} \mathrm{O}$, Wong $\mathrm{M}$, et al. Air, surface environmental, and personal protective equipment contamination by severe acute respiratory syndrome Coronavirus 2 (SARS-CoV-2) from a symptomatic patient. JAMA. 2020;323:1610-12.

13. Tran K, Cimon K, Severn M, Pessoa-Silva C, Conly J. Aerosol generating procedures and risk of transmission of acute respiratory infections to healthcare workers: a systematic review. PLoS One. 2012; 7:e35797

14. Peng X, Xu X, Li Y, Cheng L, Zhou X, Ren B. Transmission routes of 2019-nCoV and controls in dental practice. Int J Oral Sci. 2020;12:9.

15. Prather K, Wang C, Schooley R. Reducing transmission of SARSCoV-2. Science. 2020;368:1422-4.

16. Jiang $F$, Jiang X, Wang Z, Meng Z, Shao S, Anderson B, et al. Detection of severe acute respiratory syndrome Coronavirus 2 RNA on surfaces in quarantine rooms. Emerg Infect Dis. 2020;26:2162-4.

17. Li J, Fink JB, Ehrmann S. High-flow nasal cannula for COVID-19 patients: low risk of bio-aerosol dispersion. Eur Respir J. 2020;55:2000892. 